WHC-SD-EN-TI-300, Rev. 0

DISTRIBUTION

U.S. Department of Energy = Richland Operations office

E.M. Mattlin (2)

J.J. Waring

A5-15

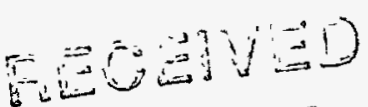

JUL 281035

$\underline{\text { GSSC }}$

J.K. Bartz

R3-82

P.J. Macbeth

R3-82

Westinghouse Hanford Company

R.E. Bolls

D.M. Korematsu-07und

(5)

T3-04

R.D. Pierce

H6-23

F.A. Ruck, III

T3-04

Central Files (2) toria.

H6-23

Unclassified Doeument

L8-04

Eontro
OSTI (2)

26

27

OSTI

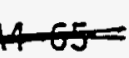

$13-36$ 


\section{DISCLAIMER}

Portions of this document may be illegible in electronic image products. Images are produced from the best available original document. 


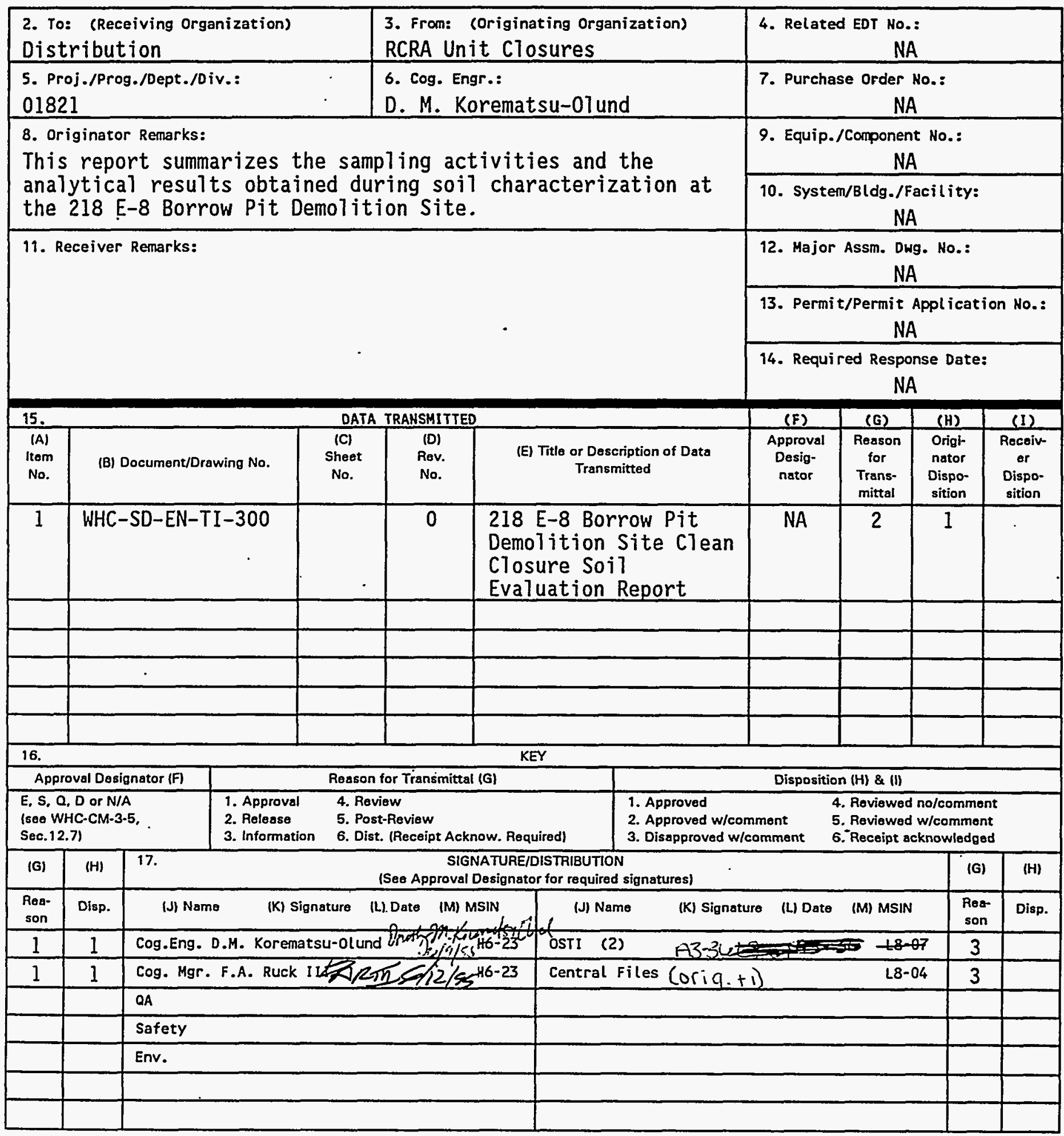

\begin{tabular}{|c|c|c|c|}
\hline 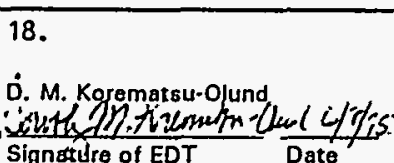 & 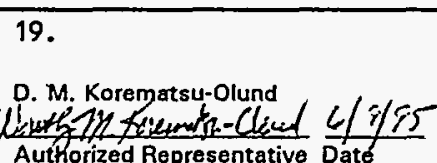 & 20. & $\begin{array}{l}\text { 21. DOE APPROVAL (if required) } \\
\text { Ctrl. No. } \\
\text {-[] Approved } \\
\text { [] Approved w/coments } \\
\text { Disanoroved w/coments }\end{array}$ \\
\hline $\begin{array}{l}\text { Signesture of EDT Date } \\
\text { Originator }\end{array}$ & $\begin{array}{l}\text { Authorized Representative Daté } \\
\text { for Receiving Organization }\end{array}$ & & \\
\hline
\end{tabular}




\section{RELEASE AUTHORIZATION}

Document Number: WHC-SD-EN-TI-300, Rev. 0

$\begin{array}{ll}\text { Document Title: } & 218 \text { E-8 Borrow Pit Demolition Site Clean Closure } \\ & \text { Soil Evaluation Report }\end{array}$

Release Date: $\quad 06 / 09 / 95$

\section{This document was reviewed following the procedures described in WHC-CM-3-4 and is:}

\section{APPROVED FOR PUBLIC RELEASE}

WHC Information Release Administration Specialist:

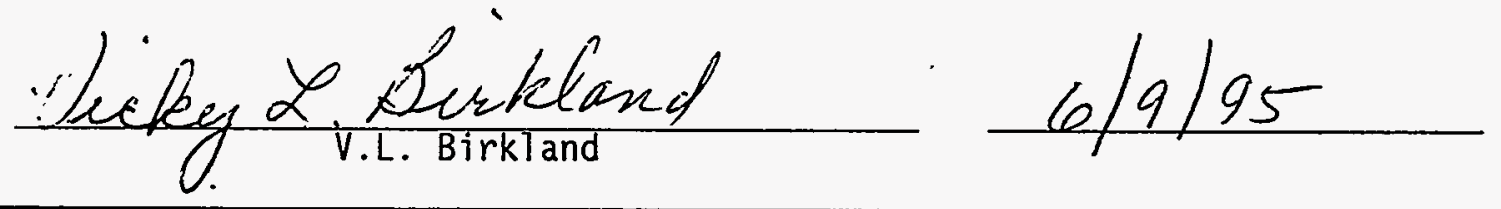

TRADEMARK DISCLAIMER. Reference herein to any specific commercial product, process, or service by trade name, trademark, manufacturer, or otherwise, does not necessarily constitute or imply its endorsement, recommendation, or favoring by the United States Government or any agency thereof or $i$ ts contractors or subcontractors.

This report has been reproduced from the best available copy. Available in paper copy and microfiche. Printed in the United States of America. Available to the U.S. Department of Energy and its contractors from:

U.S. Department of Energy

Office of Scientific and Technical Information (OSTI)

P.0. Box 62

Oak Ridge, TN 37831

Telephone: (615) 576-8401

Available to the public from:

U.S. Department of Commerce

National Technical Information Service (NTIS)

5285 Port Royal Road

Springfield, VA 22161

Telephone: - (703) 487-4650 
2. Title

218 E-8 Borrow Pit Demolition Site Clean Closure Soil Evaluation Report.

5. Key Words

Soil Evaluation, 218 E-8 Borrow Pit, Demolition Site, RCRA Closure
3. Number

WHC-SD-EN-TI-300

4. Rev Ho.

0

6. Author

Name: D. M. Korematsu-0Tund

DMil. Knematsu-Qluel

Organization/Charge Code

$01821 / A 5 G F 1$

\section{Abstract}

This report summarizes the sampling activities undertaken and the analytical results obtained in a soil sampling and analyses study performed for the 218 E-8 Borrow Pit Demolition Site (218 E-8 Demolition Site). The 218 E-8 Demolition Site is identified as a Resource Conservation and Recovery Act (RCRA) treatment unit that will be closed in accordance with the applicable laws and requlations.

No constituents of concern were found in concentrations indicating contamination of the soil by 218 E-8 Demolition Site activities. 


\title{
218 E-8 Borrow Pit Demolition Site Clean Closure Soil Evaluation Report
}

\author{
DISCLAIMER
}

This report was prepared as an account of work sponsored by an agency of the United States Government. Neither the United States Government nor any agency thereof, nor any of their employees, makes any warranty, express or implied, or assumes any legal liability or responsibility for the accuracy, completeness, or usefulness of any information, apparatus, product, or process disclosed, or represents that its use would not infringe privately owned rights. Reference herein to any specific commercial product, process, or service by trade name, trademark, manufacturer, or otherwise does not necessarily constitute or imply its endorsement, recommendation, or favoring by the United States Government or any agency thereof. The views and opinions of authors expressed herein do not necessarily state or reflect those of the United States Government or any agency thereof.

Prepared for the U.S. Department of Energy Office of Environmental Restoration and Waste Management

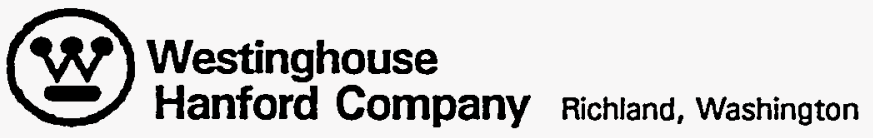

Hanford Operations and Engineering Contractor for the

U.S. Department of Energy under Contract DE-ACO6-87RL 10930 
1.0 INTRODUCTION

1.I PURPOSE AND SCOPE ....................... . . . . . 1

1.2 SUMMARY OF RESULTS .................... 1

1.3 TREATMENT UNIT INFORMATION ................. 2

2.0 SAMPLING . . . . . . . . . . . . . . . . . . . . 2

2.I SAMPLE LOCATIONS ................... 2

2.2 SAMPLE COLLECTION .................... 3

2.3 QUALITY CONTROL SAMPLES ................... 3

3.0 PERFORMANCE STANDARDS ........................... 4

3.1 BACKGROUND LEVELS .......................... 4

3.2 HEALTH-BASED LEVELS ...................... 5

4.0 ANALYSES . . . . . . . . . . . . . . . . . . 5

4.1 ORGANIC ANALYSES ..................... . . . . . . 6

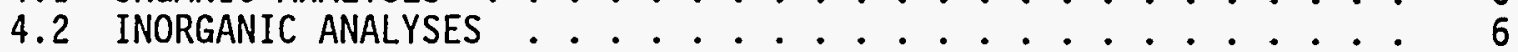

5.0 DATA VALIDATION . . . . . . . . . . . . . . . 6

6.0 DATA EVALUATION . . . . . . . . . . . . . . . . . 8

6.1 ORGANICS . . . . . . . . . . . . . . . . . 8

6.2 INORGANICS ..................... . . . . 9

7.0 CONCLUSIONS . . . . . . . . . . . . . . . . . . . . 9

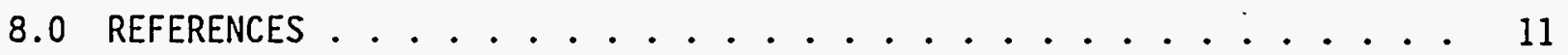

\section{FIGURES}

1. 200 East Area . . . . . . . . . . . . . . . . . . F1

2. Layout of 218 E-8 Demolition Site Closure Area . . . . . . . . . . . F2

3. 218 E-8 Demolition Site Closure Area, Sampling Locations, and Sample Intervals ..................... F3

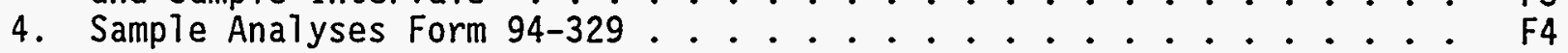

\section{TABLES}

1. Routine and Quality Control Samples................ . TI

2. 218 E-8 Demolition Site Results, Semi-Volatile Organics Analysis . . . T2

3. 218 E-8 Borrow Pit Demolition Site Soil Results, General Chemistry Analysis ........................ T3 
WHC-SD-EN-TI-300, Rev. 0

1

2

3

This page intentionally left blank. 
WHC-SD-EN-TI-300, Rev. 0

\section{E-8 BORROW PIT DEMOLITION SITE CLEAN CLOSURE SOIL EVALUATION REPORT}

\subsection{INTRODUCTION}

\subsection{PURPOSE AND SCOPE}

The purpose of this report is to describe the soil sampling performed at the 218 E-8 Borrow Pit Demolition Site (218 E-8 Demolition Site) and to present the analytical results of the verified soil samples and compare these results to clean closure criteria.

The scope of this report is the evaluation of the analyte concentrations for the nine samples taken to represent the unit soil. This report does not describe analytical methodology, nor does it provide raw analytical data or the sampling validation report. A description of the sampling plan is presented in the 218 E-8 Demolition Site closure plan (DOE-RL 1994a). The sampling plan was discussed and agreed to by all parties during the Data Quality Objective (DQ0) meeting held May 24, 1994. All analytical data were validated according to Data Validation Procedures for Chemical Analysis (WHC 1993). The Taboratory data package and data validation report have been transmitted to Ecology as the regulatory lead for closure of this unit (DOE-RL 1994c).

The 218 E-8 Demolition Site is a Resource Conservation and Recovery Act (RCRA) of 1976 treatment unit located in the 200 East Area of the Hanford Site. A single demolition event in November 1984 occurred at the $218 \mathrm{E}-8$ Demolition Site. This demolition event was a form of thermal treatment for discarded explosive chemical products. Because it will no longer be used for this thermal activity, the unit will be closed. Soil sampling of the $218 \mathrm{E}-8$ Demolition Site for the purposes of clean closure occurred in July 1994 in accordance with the 218 E-8 Demolition Site Closure Plan, Revision 1 (DOE-RL 1994a).

\subsection{SUMMARY OF RESULTS}

To meet the criteria for clean closure of the 218 E-8 Demolition Site, analytical results must verify that the concentration of all detonation activity residues is at or below action levels. Action levels are defined as levels above the Hanford Site soil background threshold levels identified in Hanford Site Background: Part 1, Soil Background for Nonradioactive Analytes (DOE-RL 1994b) and the Model Toxics Control Act (MTCA) (WAC 173-340) Method B residential levels. No constituents of concern were found in concentrations indicating contamination of the soil at the 218 E-8 Demolition Site (i.e., concentrations above action levels).

Regulator acceptance of the findings presented in this report will qualify the treatment unit for clean closure in accordance with Washington 
WHC-SD-EN-TI-300, Rev. 0

1 Administrative Code (WAC) 173-303-610, "Dangerous Waste Regulations, "without 2 further sampling or soil removal and/or decontamination.

\subsection{TREATMENT UNIT INFORMATION}

The 218 E-8 Demolition Site closure area is located in the northeast portion of the 200 East Area, as shown in Figure 1. The closure area occupies an area 20 feet ( 6 meters) by 20 feet ( 6 meters) square. It is located within a multi-use borrow pit area, as shown in Figure 2. The entire multi-use borrow pit area is approximately 600 feet (180 meters) by 900 feet (270 meters) in size with a gravelly, sparsely vegetated landscape.

In November 1984, a demolition event consisting of a single explosion occurred at the 218 E-8 Demolition Site. Discarded explosive chemical products (DOE-RL 1994a) were placed in a shallow depression, 6 to 12 inches (15 to 30 centimeters) deep, dug expressly for the demolition activity. The discarded explosive chemical products were detonated in their original metal and glass containers. Conventional explosives (i.e., nitroglycerin dynamite and detonating cord) were placed around and on top of the chemical containers. After the detonation event, the area was inspected to confirm that no intact chemicals or containers remained.

\subsection{SAMPLING}

Soil sampling was performed on July 12, 1994, as specified in the sampling and analys is plan (SAP) provided in the 218 E-8 Demolition Site Closure Plan (DOE-RL 1994a). Nine samples were collected (8 samples and 1 co-located duplicate). Two blank samples were included during sampling: a trip blank and an equipment blank. The trip blank is used to test for contamination due to sample handling. The equipment blank is used to. determine whether decontamination of sampling equipment is adequate.

\subsection{SAMPLE LOCATIONS}

The sample locations and the intervals are shown in Figure 3 . The nine soil samples were taken within a 5.5-foot (1.7-meter)-radius centered around the blasting pit. Before sampling, the blasting pit was reconstructed by removing wind-blown sand to create a 6 -inch ( 15 centimeter)-deep, 3-foot (91-centimeter) diameter hole (original diameter 1.5 feet [ 46 centimeters]). Sample intervals within the reconstructed crater (Figure 3 , shaded area) were based on the configuration of the reconstructed crater. All nine sample locations were authoritatively selected to ensure comprehensive coverage in the inner radius of the pit and to account for the effects of prevailing wind patterns on the pit. The co-located duplicate sample was taken at the center of the crater at an interval of 0 to 6 inches ( 0 to 15 centimeters). 
WHC-SD-EN-TI-300, Rev. 0

\subsection{SAMPLE COLLECTION}

The nine samples required by the closure plan were assigned Hanford Environmental Information System (HEIS) (WHC 1990) numbers BOCBN1, BOCBN2, and B0C961 through BOC969 (figure 3). The trip blank sample was numbered BOCBN2 and the equipment blank sample was numbered B0C964.

Engineering support personnel used hand tools (i.e., stainless stee] spoon and bowl) to obtain the soil samples in accordance with information provided in Figure 3. Sampling depth ranged from 0 to 18 inches $(0$ to 46 centimeters). Samples were collected for offsite laboratory analyses per SW-846 as requested on the Sample Analys is Form 94-329 (Figure 4). The sampling equipment was decontaminated in the $1706 \mathrm{KE}$ Laboratory in accordance with Environmental Investigation Instruction 5.5, "Laboratory Cleaning of RCRA/CERCLA Sampling Equipment" (WHC 1988). A complete set of decontaminated equipment was provided for each sample. All sampling equipment was later returned to the $1706 \mathrm{KE}$ Laboratory for decontamination.

Because samples going offsite are required to show a certificate of nondangerous radioactivity, additional al iquots were taken for total activity readings. These al iquots were transported to the 222-S Laboratory on the following day July 13, 1994. The evaluation of the total activity results allowed release of the samples for offsite transfer on July 14, 1994. All samples were packaged, handled, and shipped in accordance with WHC Environmental Investigations Instructions (WHC 1988). All samples were cooled to $4{ }^{\circ} \mathrm{Cel}$ sius during storage and transportation to the offsite laboratory. Samples are listed in Table 1 .

\subsection{QUALITY CONTROL SAMPLES}

Figure 3 summarizes sample identification, location, and QC designation.

A fuplicate sample (BOC953) was taken at the location of sample B0C952. The sample number B0C952 and the co-located duplicate were taken from the center of the crater at an interval of 0 to 6 inches ( 0 to 15 centimeters). Duplicate samples are collected as close as possible to the same point in space and time; however, they are stored in separate containers and analyzed independently. Duplicates are used to estimate the precision of the sampling process.

Trip blanks are used when samples are taken for volatile organics analysis. The trip blank for this study consisted of clean sand that was placed in a sample bottle in an uncontaminated area. The trip blank was subjected to the same handling as the routine samples and was analyzed to determine if contamination originated from the sample container or transportation and storage procedures. The trip blank was submitted to the analytical laboratory with the routine samples.

Equipment blanks consist of clean sand poured over or through the sampling device after decontamination; these blanks are collected in a sample bottle and transported to the laboratory for analysis. Equipment blanks test 
WHC-SD-EN-TI-300, Rev. 0

\begin{abstract}
for residual contamination from inadequate decontamination of the sampling equipment at the $1706 \mathrm{KE}$ Facility. One equipment blank was collected after the sampling event was completed.
\end{abstract}

\title{
3.0 PERFORMANCE STANDARDS
}

The performance standards, or action levels, for soils are defined in the 218 E-8 Demolition Site Closure Plan (DOE-RL 1994a), Chapter 6, Section 6.1. To meet action levels for clean closure, analytical results must verify that potentially dangerous waste constituents treated at the unit are not present in concentrations above these levels. Action levels are defined as levels above the Hanford Site soil background threshold levels identified in Hanford Site Background: Part 1, Soil Background for Nonradioactive Analytes (DOE-RL 1994b) and Mode7 Toxics Control Act (MTCA) (WAC 173-340) Method B levels. If analysis determines that concentration are above both guidelines, a phase two investigation will be developed. Additional information on the Hanford Site Background threshold levels is provided in Section 3.1 and is listed in Tables 2 and 3 . Information on MTCA Method B health-based levels is provided in Section 3.2 and calculations are described in Model Toxics Control Act (MTCA) [WAC 173-340-740 (3)(a)( $i$ ii)] Method B. In this report, the analytical results have been evaluated and compared with action levels to verify that the concentration of all detonation activity residues is at or below action levels.

\subsection{BACKGROUND LEVELS}

The background action levels used in this report are based on a sitewide approach to determining background levels and were developed as an alternative to local unit-based background determinations at the Hanford Site (DOE-RL 1994b). Using local background for each treatment, storage, and/or disposal (TSD) unit can lead to different definitions of contamination and different assessments of remediation goals and risk for various TSD units. The Hanford Site Background approach is based on the premise that (1) the waste management units are located on or in a common sequence of vadose zone sediments, and (2) the basic characteristics that control the chemical composition of these sediments are similar throughout the Hanford Site. The range of natural soil compositions is used to establish a single set of soil background data. Use of the Hanford Site Background for environmental restoration on the Hanford Site is technically preferable to the use of the unit-based background because the former more accurately represents the natural variability in soil composition and also provides a more consistent and efficient basis for evaluating contamination in soil.

The Hanford Site Background threshold levels are summarized in Tables 2 and 3. The background threshold is the concentration level defining the upper limit of the background population. Background thresholds are based on a tolerance interval approach. The calculated threshold levels depend on the confidence interval and percentile used in the calculation. The 
WHC-SD-EN-TI-300, Rev. 0

1

WAC 173-340-708(11)(d) specifies a tolerance coefficient of 95 percent and a coverage of 95 percent. The Hanford.Site Background threshold levels are based on this 95/95 confidence interval. Statistical calculations are described in the source document (DOE-RL 1994b).

\subsection{HEALTH-BASED LEVELS}

The health-based action levels used in this report are based on calculations from the equations, risk levels, and exposure assumptions found in the MTCA Method B [WAC 173-340-740 (3)(a)( $i$ i $i)$ ]. For noncarcinogens, the principal variable is the reference dose. The reference dose, as defined in the Environmental Protection Agency's (EPA) Integrated Risk Information System (IRIS) database (EPA 1995), is an estimate of a daily exposure to the human population that likely is to be without an appreciable risk of deleterious effects during a lifetime. For carcinogens, the cancer slope factor is the basis for determining human health effects; it is a measurement of the risk per unit dose. The reference dose and the cancer slope factor are chemicalspecific and are obtained from IRIS. If not available in IRIS, secondary sources for these toxicity values include the Ecology Cleanup Levels and Risk Calculation database (Ecology 1995) and EPA Health Effects Assessment Summary Tables (EPA 1994).

\subsection{ANALYSES}

All samples were analyzed for volatile organic compounds (VOCs), detonation residues, anions, and total nitrogen. Semi-volatile organic compound (Semi-VOC) analysis was performed on selected samples (Figure 3 ). Semi-VOCs are not part of the inventory of known discarded explosive chemical products that were detonated at the 218 E-8 Demolition Site, nor are they Tisted on the inventory of known detonation materials used at the 218 E-8 Demolition Site. However, during the .DQO meeting all parties agreed to analyze a limited number of samples for semi-VOC for informational purposes.

A11 samples were sent to IT-Quanterra Laboratory in Knoxville, Tennessee, for analysis. Table 1 lists the analytical methods for 218 E-8 Demolition site soils. Anions and total nitrogen results are grouped together in the data package "General Chemistry" and will be discussed in this report under the subtitle of "Inorganic Compounds." Each analyte group, except nitroexplosives and VOCs, has a concentration comparison table that lists and identifies chemical concentrations (see Tables 2 and 3 ). All known nitroexplosives and VOCs data were reported as undetected. No further evaluation will be presented for these undetected analytes.

Al1 analytical data were validated according to Data Validation Procedures for Chemical Analysis (WHC 1993) (refer to Section 5.0). 
WHC-SD-EN-TI-300, Rev. 0

\subsection{ORGANIC ANALYSES}

Samples were analyzed for VOCs and semi-VOCs, including standard target analytes and Appendix IX VOCs and semi-VOCs, using gas chromatography/mass spectroscopy (GS/MS), which is based on EPA SW-846 methods 8240 and 8270 . Any unidentified compounds were subjected to a computer-generated Tibrary search and mass spectral interpretation. Those unidentified analytes that generaliy correlate with known compound spectra are listed as tentatively identified compounds (TICs). The volatile organic analysis was performed by purge and trap with capillary column on a GC/MS. All samples were analyzed and all analytes were reported as undetected. Matrix spike and matrix duplicate samples were analyzed for sample BOC961 and met all QC method specified limits.

The semi-VOC analysis was performed by direct injection of sample extract on a capillary column on a GC/MS. The samples did not contain any Appendix IX compounds. Matrix spike and matrix spike duplicate were analyzed for sample B0C961 and passed all QC criteria.

\subsection{INORGANIC ANALYSES}

Samples were analyzed for the following inorganic analytes: fluoride, chloride, phosphate, sulfate, nitrate, and nitrite. The EPA Method 300 (EPA 1993) was used to determine the fluoride, chloride, phosphate, and sulfate concentrations. The EPA Method 353.2 (EPA 1993) was used to determine the nitrate/nitrite concentrations. It should be noted that EPA Method 300 (EPA 1993) reports values for nitrate and nitrite and these are included in the validation data package (DOE-RL 1994c). However, for the purpose of this report, only the results from Method 353.2 (EPA 1993) will be used as agreed to during the DQO process.

\subsection{DATA VALIDATION}

Data validation was performed by Golder Associates Inc. (GAI), in accordance with Leve] $D$ as defined in Data Validation Procedures for Chemical Analysis (WHC 1993). Level D validation includes evaluation and qualification of results based on analytical holding times, method blank results, matrix spikes and duplicates, surrogate recoveries, and analytical method blanks.

The criteria and limits for the validation procedures are listed in the source document. Results of the data validators' review of the QC applied in this sampling event were transmitted to the regulators with the validated data packages (DOE-RL 1994C).

The data validation procedure establishes the following qualifiers and definitions to describe the associated data. 
WHC-SD-EN-TI-300, Rev. 0

$U$ Indicates the compound or analyte was analyzed for and not detected in the sample.

UJ Indicates the compound or analyte was analyzed for and not detected in the sample. Because of a quality control deficiency identified during data validation, the associated quantitation limit is an estimate. These data are useable for decision making purposes.

$\mathrm{J}$ Indicates the compound or analyte was analyzed for and detected. The associated concentration is an estimate by the laboratory because it is below the method detection limit. These data are usable for decision making purposes.

JN Indicates a tentatively identified compounds (TIC) that has been determined to be valid in terms of identification and quantitation.

UR Indicates the compound or analyte was analyzed for and not detected in the sample. As a result of a major quality control deficiency identified during data validation, the associated data have been qualified as unusable for decision making purposes.

$\mathrm{R}$ Indicates the compound or analyte was analyzed for and detected. As a result of a major quality control deficiency identified during data validation, the concentration reported has been qualified as unusable. The associated data should be considered unusable for decision-making purposes.

B For organic data, indicates that the analyte was detected in both the sample and the associated blank. For inorganic data, indicates that the analyte concentration is less than the contract required detection 7 imit, but greater than the instrument detection limits.

A11 TICs reported during the organics analyses are deemed as estimated and presumptive and are qualified as estimated during the data validation process (WHC 1993).

Some discrepancies were noted in the validation of the laboratory data resulting in the data being qualified. The qualifiers are listed in Tables 2 and 3 . These qualifiers were applied to the data as described and required in the data validation guidelines (WHC 1993).

- For the VOA, methylene chloride and acetone were detected in the laboratory blank. This resulted in some data being qualified as non-detect $(U)$.

- For general chemistry analyses (anions), the holding times for some phosphate results were exceeded and the applicable results were qualified as estimated ( $J$ ) or rejected (R). However, this is due to applying holding times established for water samples to these soil samples. There are currently no holding times established for soil samples. 
WHC-SD-EN-TI-300, Rev. 0

- For chloride, sample spike recovery was slightly below control limits and the applicable results were qualified as estimated ( $\mathrm{J}$ ).

- No deficiencies were noted for the semi-VOA and nitroexplosives data.

Additional information on the above noted laboratory discrepancies can be found in the data validation packages (DOE-RL 1994C).

\subsection{DATA EVALUATION}

The closure plan proposed comparing concentrations in soil of constituents of concern to health-based action levels. Analytical results below the detection limits are not considered to signify contamination. The samples will be considered clean with respect to that analyte. The healthbased action levels will be based on MTCA Method B or Hanford Site Background threshold levels for soil. Any analyte found in concentrations greater than this health-based level will require further evaluation.

\subsection{ORGANICS}

No VOCs were reported. For the semi-volatiles analyses, discussed below, al1 of the compounds found can be dismissed due to their low concentrations or their status as common laboratory contaminants.

Phthalate compounds were identified in two samples including the equipment blank (B0C962, BOC964). According to data validation guidelines, these are common laboratory contaminants when detected in concentrations less than 4,000 parts per billion in soil samples. Because all values were below this limit, all phthalate compounds are being dismissed as attributable to laboratory contaminants.

There are no Hanford Site Background threshold levels or MTCA, Method B levels or practical quantitative level (PQL) for TICs. TICs are purely a qualitative measure of whether or not a compound is detected, the result is strictly estimated. The TICs found in this study are not an EPA 1 isted hazardous substance ( 40 CFR 261) nor are they a WAC dangerous waste constituents having a waste designation level (WAC 173-303). No toxicity (oral reference dose) information or carcinogenicity (cancer potency factor) information is available from the EPA. Because TICs have no established action levels or bearing on dangerous waste regulations and are present at such low concentration levels, they are considered to be below a level of concern.

The field duplicate sample B0C962 contained TICs (identified in Table 2). that were not found in the original sample (number B0C961). No constituents except a phthalate were detected in the duplicate. Compounds not found in both the original and duplicate samples do not show reproducibility and are therefore dismissed as anomalies. 
TICs identified as hexanoic acid, hexadecanoic acid and 2-methoxy-2propoxy propane were found in the equipment blank in low concentrations and can be attributed to, and dismissed as, equipment contamination.

In sample number BOC963, one TIC'was identified as pentacosane at 260 parts per billion. Pentacosane is a long single chain hydrocarbon categorized as a wax bi-product. It is not subject to the dangerous waste regulations and is present at such low concentration levels that it is considered to be below a level of concern.

A TIC identified as 2,6-dimethyl-heptadecane was detected in sample numbers $\mathrm{BOC} 961$, BOC962, and BOC963 in the 100 parts per billions range. The 2,6-dimethy1-heptadecane is not subject to the dangerous waste regulations and is present at such low concentration levels that it is considered to be below a level of concern.

\subsection{INORGANICS}

No nitroexplosives were reported. The anions analyses are summarized in Table 3. Chloride and phosphate results that were qualified with a $\mathrm{J}$ indicate that the data are estimated but considered usable for decision making purposes through data validation. Anion analyses reported above the laboratory instrumentation detection limits were compared to MTCA, Method B and/or Hanford Site Background threshold levels (DOE-RL 1994b). Fluoride, chloride, phosphate, sulfate, and nitrite-nitrate concentrations were all found to be below action levels indicating no contamination present. Chloride and sulfate were detected in the equipment blank indicating that the source was from the sampling equipment.

\subsection{CONCLUSIONS}

The sampling and analysis activities identified few analyte concentrations above detection. No volatile organic compounds or nitroexplosives were detected. When MTCA, Method B and Hanford Site Background threshold levels were available, all analytes were below action levels. Of the semi-VOCs for which no action levels were available, all were TICS whose concentrations were below quantitation limits. The semi-VOC detections were dismissed for any one of the following reasons:

- low concentrations

- attributed to common laboratory contaminates

- contamination by equipment

- constituents were not hazardous substances or dangerous waste constituents. 
WHC-SD-EN-TI-300, Rev. 0

1 All inorganic concentrations are below MTCA, Method B and/or Hanford Site Background threshold levels, indicating no inorganic contamination is present at the 218 E-8 Demolition Site.

In summary, the analytical results for the 218 E-8 Demolition Site soils meet the criteria for clean closure verifying that the concentration of all detonation activity residues are below action levels. No constituents of concern were found in concentrations indicating contamination of the soil at the 218 E-8 Demolition Site (i.e., concentrations above action levels).

10 Consequently, under the provisions of WAC 173-303-610, this RCRA unit

Il qualifies for clean closure. 


\subsection{REFERENCES}

DOE-RL, 1994a, 218 E-8 Borrow Pit Demolition Site Closure Plan, DOE/RL-92-53, Rev. 1, U.S. Department of Energy, Richland Operations Office, Richland, Washington.

DOE-RL, 1994b, Hanford Site Background: Part 1, Soil Background for Nonradioactive Analytes, DOE/RL-92-24, Rev. 2, U.S. Department of Energy, Richland Operations Office, Richland, Washington.

DOE-RL, 1994c, Letter J. D. Bauer, RL; to D. L. Lundstrom, Ecology; and D. R. Sherwood, EPA, "Submittal of Validated Data for the 218 E-8 Borrow Pit Demolition Site Soil Sampling and 200 West Area Ash Pit Demolition Site Soil Sampling", dated November 7, 1994, 95-PCA-043, U.S. Department of Energy, Richland Operations Office, Richland, Washington.

Ecology, EPA, and DOE, 1994, Hanford Federal Facility Agreement and Consent order, 2 vols., Washington State Department of Ecology,

U.S. Environmental Protection Agency, and U.S. Department of Energy, Olympia, Washington.

Ecology, 1994, Guidance for Clean Closure of Dangerous Waste Facilities, August 1994, Publication \#94-111, Washington State Department of Ecology, 01 ympia, Washington.

Ecology, 1995, Model Toxic Control Act Cleanup Levels and Risk Calculations Update, Publication \#94-145, Washington State Department of Ecology, olympia, Washington.

EPA, 1986, Test Methods for the Evaluation of Solid Waste: Physical/Chemical Methods, SW-846, as amended, U.S. Environmental Protection Agency, Washington, D.C.

EPA, 1993, Methods for Chemicai Analysis of Water and Waste, EMSL-Ci, EPA-600/4-79-020, Revised March 1993, U.S. Environmental Protection Agency, Washington, D.C.

EPA, 1994, Health Effects Assessment Summary Tables, U.S. Environmental Protection Agency, Washington, D.C.

EPA, 1995, Integrated Risk Information System, (online information system, updated periodically) Environmental Criteria and Assessment office, U.S. Environmental Protection Agency, Cincinnati, Ohio.

Resource Conservation and Recovery Act of 1976, 42 USC 6901 et seq.

WAC 173-303, "Dangerous Waste Regulations," Washington Administrative Code, as amended.

WAC 173-340, "The Model Toxics Control Act Cleanup Regulations, "Washington Administrative Code, as amended. 
WHC-SD-EN-TI-300, Rev. 0

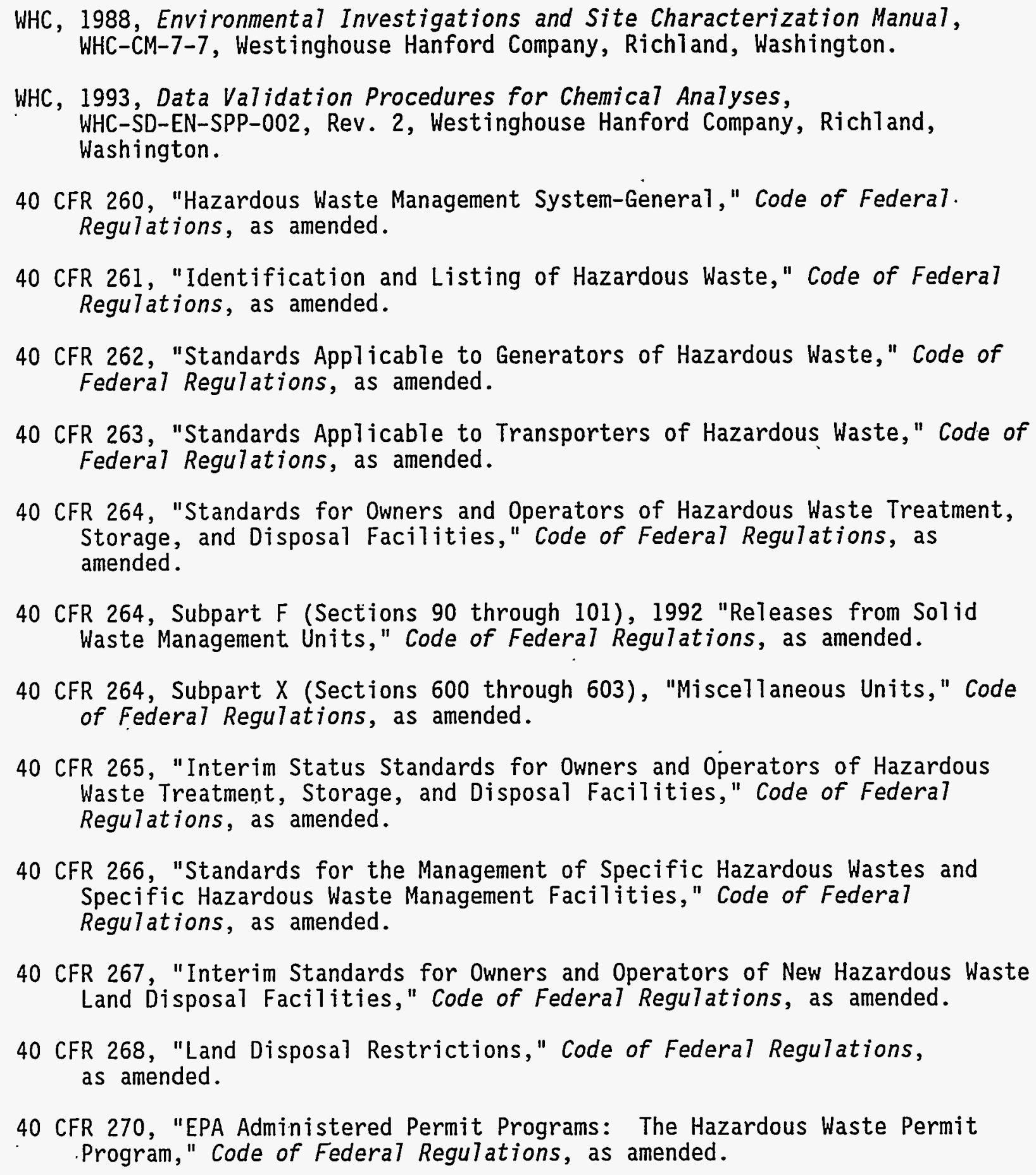

40 CFR 264, Subpart F (Sections 90 through 101), 1992 "Releases from Solid Waste Management Units," Code of Federal Regulations, as amended.

40 CFR 264, Subpart X (Sections 600 through 603), "Miscellaneous Units," Code of Federal Regulations, as amended.

40 CFR 265, "Interim Status Standards for Owners and Operators of Hazardous Waste Treatment, Storage, and Disposal Facilities," Code of Federal Regulations, as amended.

40 CFR 266, "Standards for the Management of Specific Hazardous Wastes and Specific Hazardous Waste Management Facilities," Code of Federal Regulations, as amended.

40 CFR 267, "Interim Standards for Owners and Operators of New Hazardous Waste Land Disposal Facilities," Code of Federal Regulations, as amended.

40 CFR 268, "Land Disposal Restrictions," Code of Federal Regulations, as amended.

40 CFR 270, "EPA Administered Permit Programs: The Hazardous Waste Permit .Program," Code of Federal Regulations, as amended. 


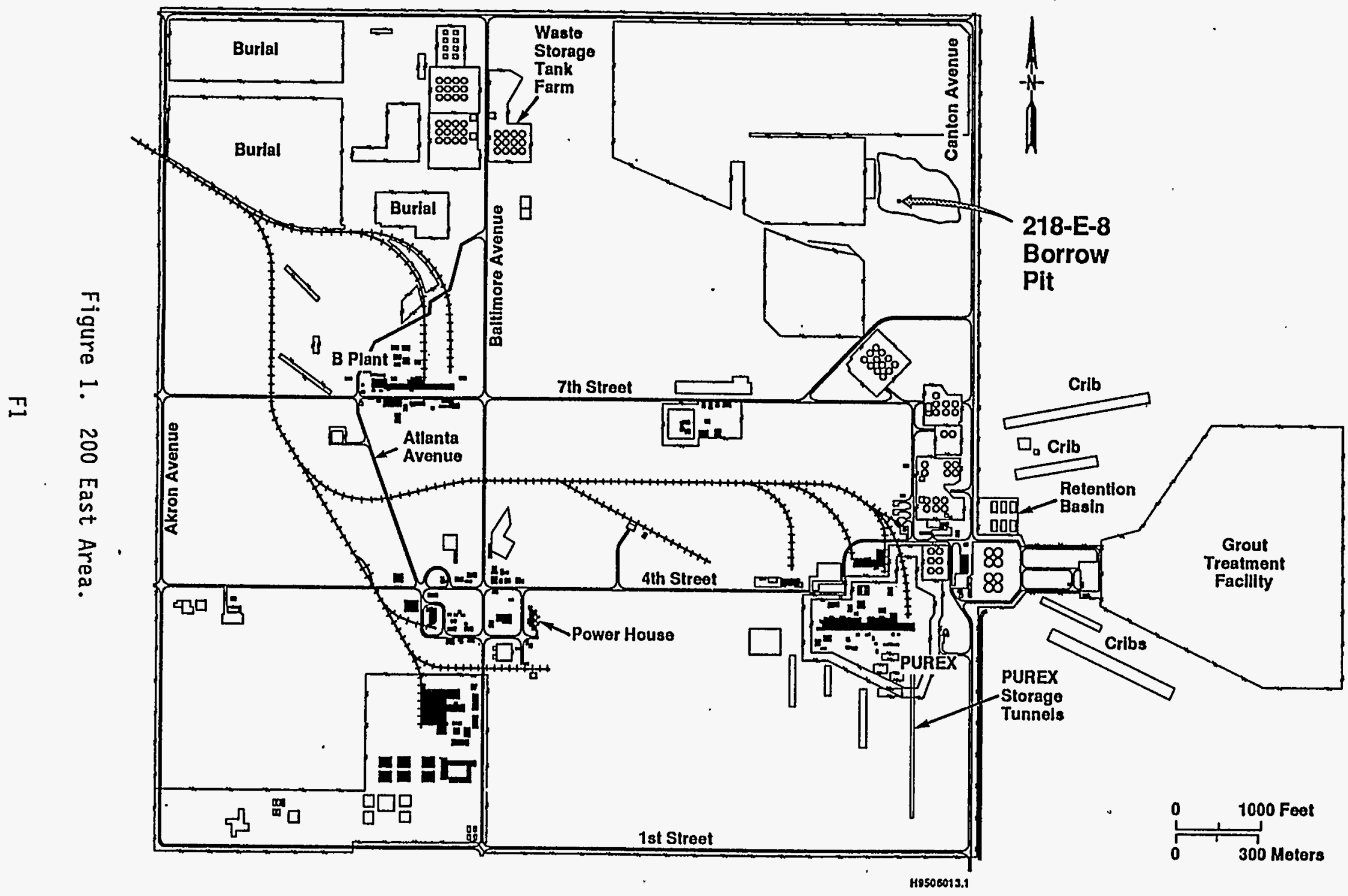


WHC-SD-EN-TI-300, Rev. 0
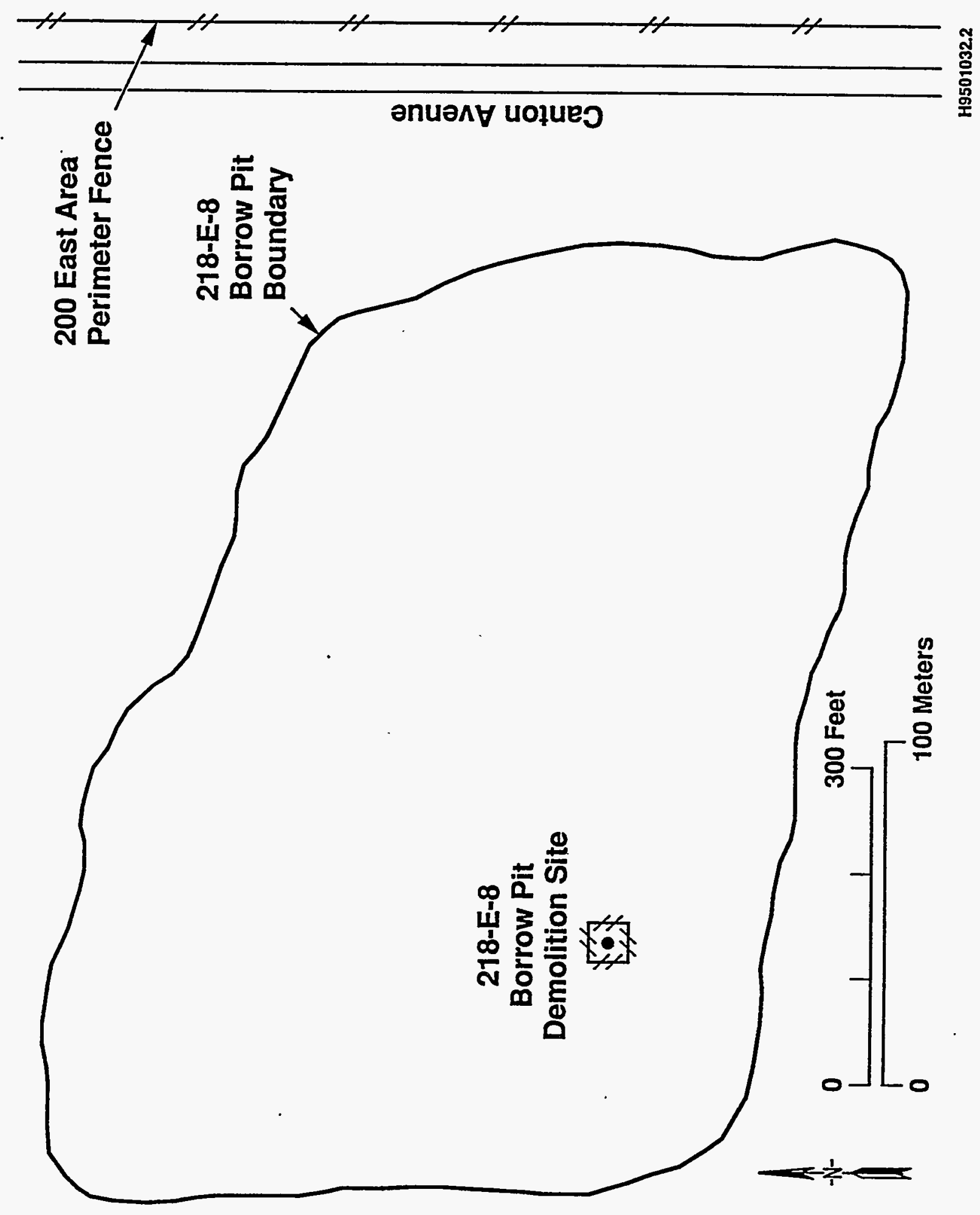

Figure 2. Layout of 218 E-8 Demolition Site Closure Area. 


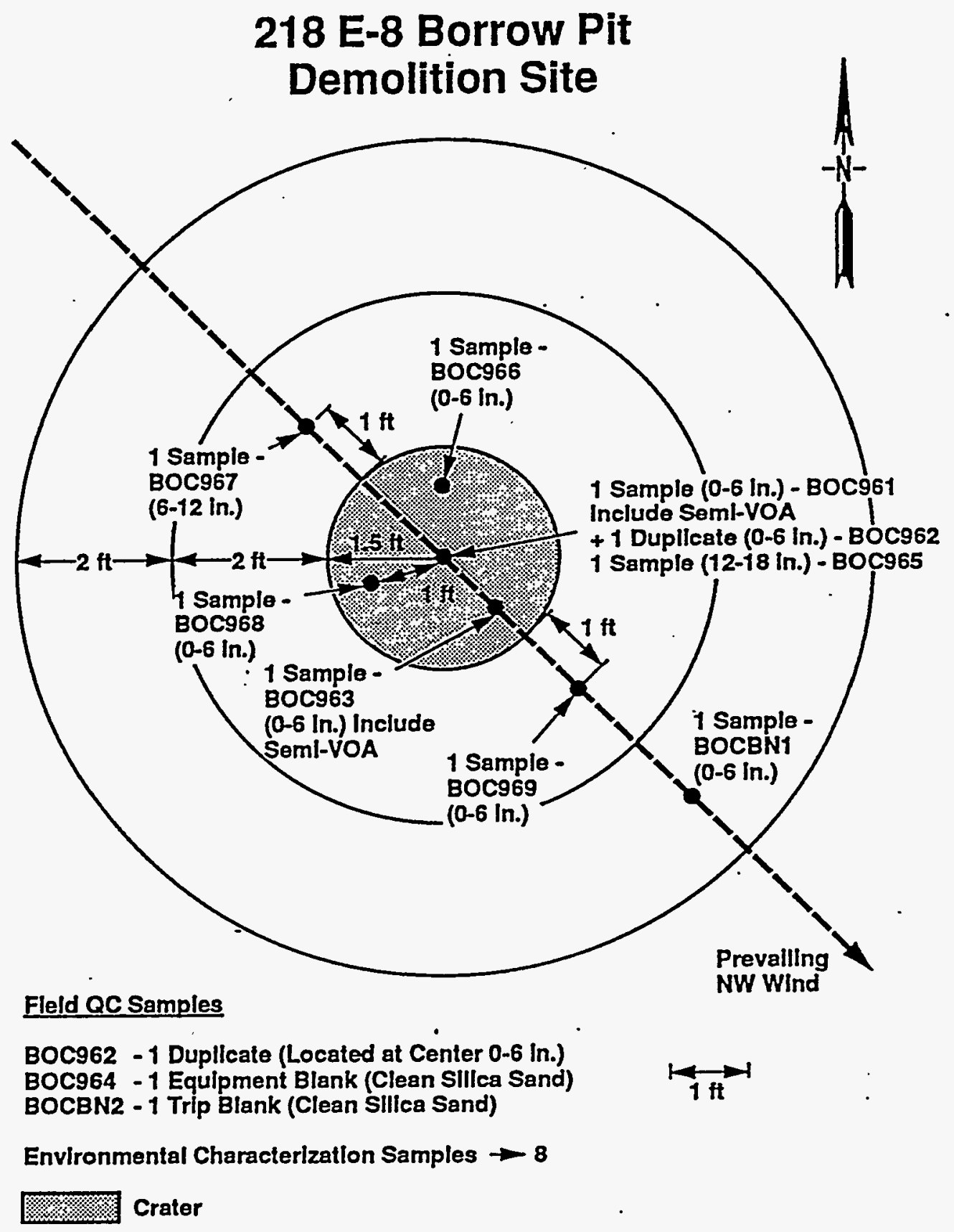

H9405002.2

Figure 3. 218 E-8 Demolition Site Closure Area, Sampling Locations, and Sample Intervals. 


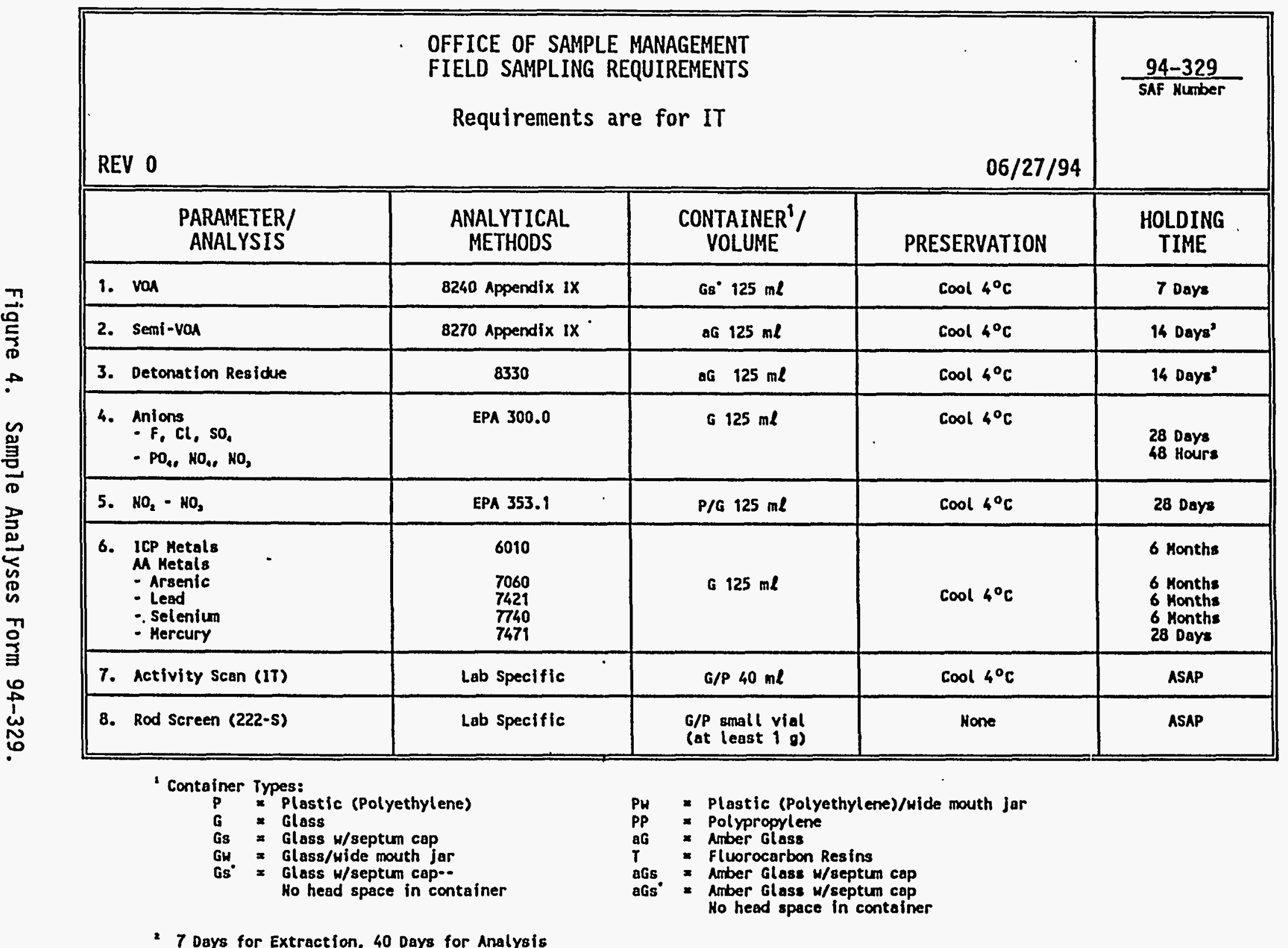

2 14 Days for Extroction, 40 Days for Analysis 
WHC-SD-EN-TI-300, Rev. 0

Table 1. Routine and Quality Control Samples.

\section{2}

4

5

7

8

9

10

11

12

13

14

15

16

$17:$

\begin{tabular}{|c|c|c|}
\hline Sample number & Constituent Analysis ${ }^{a}$ & Analytical Method \\
\hline BOC961 & $\begin{array}{l}\text { VOC, Semi-VOC, Detonation } \\
\text { residue, Anions, TN }\end{array}$ & $\begin{array}{l}\text { SW-846:8240,8270,8330 } \\
\text { EPA } 300.0,353^{\mathrm{C}}\end{array}$ \\
\hline $\begin{array}{l}\text { BOC962 } \\
\text { Duplicate }\end{array}$ & $\begin{array}{l}\text { VOC, Semi-VOC, Detonation } \\
\text { residue, Anions, TN }\end{array}$ & $\begin{array}{l}\text { SW-846:8240, } 8270,8330 \\
\text { EPA } 300.0,353\end{array}$ \\
\hline BOC963 & $\begin{array}{l}\text { VOC, Semi-VOC, Detonation } \\
\text { residue, Anions, TN }\end{array}$ & $\begin{array}{l}\text { SW-846:8240, } 8270,8330 \\
\text { EPA } 300.0,353\end{array}$ \\
\hline $\begin{array}{l}\text { BOC964 } \\
\text { Equipment } \\
\text { Blank }\end{array}$ & $\begin{array}{l}\text { VOC, Semi-VOC, Detonation } \\
\text { residue, Anions, TN }\end{array}$ & $\begin{array}{l}\text { SW-846:8240, } 8270,8330 \\
\text { EPA } 300.0,353\end{array}$ \\
\hline BOC965 & $\begin{array}{l}\text { VOC, Detonation residue, } \\
\text { Anions, TN }\end{array}$ & $\begin{array}{l}\text { SW-846:8240, } 8330 \\
\text { EPA } 300.0,353\end{array}$ \\
\hline BOC966 & $\begin{array}{l}\text { VoC, Detonation residue, } \\
\text { Anions, TN }\end{array}$ & $\begin{array}{l}\text { SW-846:8240, } 8330 \\
\text { EPA } 300.0,353\end{array}$ \\
\hline BOC967 & $\begin{array}{l}\text { VOC, Detonation residue, } \\
\text { Anions, TN }\end{array}$ & $\begin{array}{l}\text { SW-846:8240, } 8330 \\
\text { EPA } 300.0,353\end{array}$ \\
\hline BOC968 & $\begin{array}{l}\text { VOC, Detonation residue, } \\
\text { Anions, TN }\end{array}$ & $\begin{array}{l}\text { SW-846:8240, } 8330 \\
\text { EPA } 300.0,353\end{array}$ \\
\hline BOC969 & $\begin{array}{l}\text { VOC, Detonation residue, } \\
\text { Anions, TN }\end{array}$ & $\begin{array}{l}\text { SW-846:8240, } 8330 \\
\text { EPA 300.0, 353 }\end{array}$ \\
\hline BOCBN1 & $\begin{array}{l}\text { VOC, Detonation residue, } \\
\text { Anions, TN }\end{array}$ & $\begin{array}{l}\text { SH-846:8240, } 8330 \\
\text { EPA } 300.0,353\end{array}$ \\
\hline $\begin{array}{l}\text { BOCBN2 } \\
\text { Trip Blank }\end{array}$ & VOC & SW-846:8240 \\
\hline
\end{tabular}

NOTE: All samples submitted to IT-Quanterra, Knoxville, Tenn.

$T N=$ nitrate-nitrite

a Sample locations and analytical requirements in Figure 3 and 4 .

b EPA 1986.

c EPA 1993. 
Table 2. 218 E-8 Demolition Site Results, Semi-Volatile Organics Analysis.

\begin{tabular}{|c|c|c|c|c|c|c|c|}
\hline $\begin{array}{l}\text { Sample } \\
\text { number }\end{array}$ & Name of Constituent & $\mathrm{CAS}^{\mathrm{a}}$ & Qualifiers & $\begin{array}{l}\text { Concentration } \\
\mu \mathrm{g} / \mathrm{kg}\end{array}$ & $\begin{array}{l}\text { MTCA Method } B \\
\text { Cleanup Level } \\
\mu \mathrm{g} / \mathrm{kg}\end{array}$ & $\begin{array}{c}\text { Hanford site Soil } \\
\text { Background } \\
95 / 95 \text { threshold } \\
\mu \mathrm{g} / \mathrm{kg}\end{array}$ & $\begin{array}{c}\text { Hanford si te } \\
\text { Background } \\
\text { Maximum Conc. } \\
\mu \mathrm{g} / \mathrm{kg} \\
\end{array}$ \\
\hline BOC961 & $\begin{array}{l}\text { TIC: } \\
2,6,- \text { Dimethyl - Heptadecane }\end{array}$ & $54105-67-8$ & $\mathrm{JN}$ & 140.00 & NA & NA & NA \\
\hline $\begin{array}{l}\text { Boc962 } \\
\text { Dupl icate }\end{array}$ & $\begin{array}{l}\text { Di-N-Butylph thal ate } \\
\text { TIC: } \\
\text { 2,6,-Dimethyl - Heptadecane } \\
\text { Hexadecanoic Acid } \\
\text { 4,7-D imethylundecane } \\
\text { Pentadecane } \\
\text { Octacosane }\end{array}$ & $\begin{array}{l}84-74-2 \\
54105-67-8 \\
57-10-3 \\
17301-32-5 \\
629-62-9 \\
630-02-4 \\
\end{array}$ & $\begin{array}{l}J \\
J N \\
J N \\
J N \\
J N \\
J N \\
\end{array}$ & $\begin{array}{l}100.00 \\
92.0 \\
130.0 \\
78.00 \\
75.00 \\
220.0 \\
\end{array}$ & $\begin{array}{l}8000.0 \\
\text { NA } \\
\text { NA } \\
\text { NA } \\
\text { NA } \\
\text { NA }\end{array}$ & $\begin{array}{l}\text { NA } \\
\text { NA } \\
\text { NA } \\
\text { NA } \\
\text { NA } \\
\text { NA }\end{array}$ & $\begin{array}{l}\text { NA } \\
\text { NA } \\
\text { NA } \\
\text { NA } \\
\text { NA } \\
\text { NA }\end{array}$ \\
\hline BOC963 & $\begin{array}{l}\text { TIC: } \\
2,6 \text {-D imethyl - Heptadecane } \\
\text { Pentacosane }\end{array}$ & $\begin{array}{l}54105-67-8 \\
629-99-2\end{array}$ & $\begin{array}{l}\mathrm{JN} \\
\mathrm{JN}\end{array}$ & $\begin{array}{l}87.00 \\
260.0\end{array}$ & $\begin{array}{l}\text { NA } \\
\text { NA }\end{array}$ & $\begin{array}{l}\text { NA } \\
\text { NA }\end{array}$ & $\begin{array}{l}\text { NA } \\
\text { NA }\end{array}$ \\
\hline $\begin{array}{l}\text { Bocis } \\
\text { equip } \\
\text { blank }\end{array}$ & $\begin{array}{l}\text { Di-N-Butylphthalate } \\
\text { Bis(2-ethylhexly)phthalate } \\
\text { TIC: } \\
\text { Hexanoic Acid } \\
\text { Hexadecanoic Acid } \\
\text { 2-methoxy-2-propoxy propane }\end{array}$ & $\begin{array}{l}84-74-2 \\
117-81-7 \\
1,42-62-1 \\
57-10-3\end{array}$ & $\begin{array}{l}J \\
\text { BJ } \\
J N \\
J N\end{array}$ & $\begin{array}{l}78.0 \\
61.0 \\
77.00 \\
180.0 \\
2100.0\end{array}$ & $\begin{array}{l}8000.0 \\
71.0 \\
\text { NA } \\
\text { NA } \\
\text { NA }\end{array}$ & $\begin{array}{l}\text { NA } \\
\text { NA } \\
\text { NA } \\
\text { NA } \\
\text { NA }\end{array}$ & $\begin{array}{l}\text { NA } \\
\text { NA } \\
\text { NA } \\
\text { NA } \\
\text { NA }\end{array}$ \\
\hline
\end{tabular}

$\mu g / k g=$ microgram/kilogram (parts per billion)

$N A=$ not available

$J=$ Indicates the compound or analyte was analyzed for and detected. The associated concentration is an estimate, by the laboratory because it is below the method detection limit.

$J N=$ Tentatively identified compounds (TICS) were reported in the samples and deemed estimated and presumptive

$\mathrm{BJ}=$ For organic data, indicates that the compound was detected in both the sample and the associated method blank. The associated concentration is estimated.

a $=$ Chemical Abstract Services

b a Calculation found in Model Toxic Control Act (173-340-740)

30 Note: MTCA, Method B, use the lowest of the two cleanup levels, cancer or noncancer-based, for implementation in closure plans. 


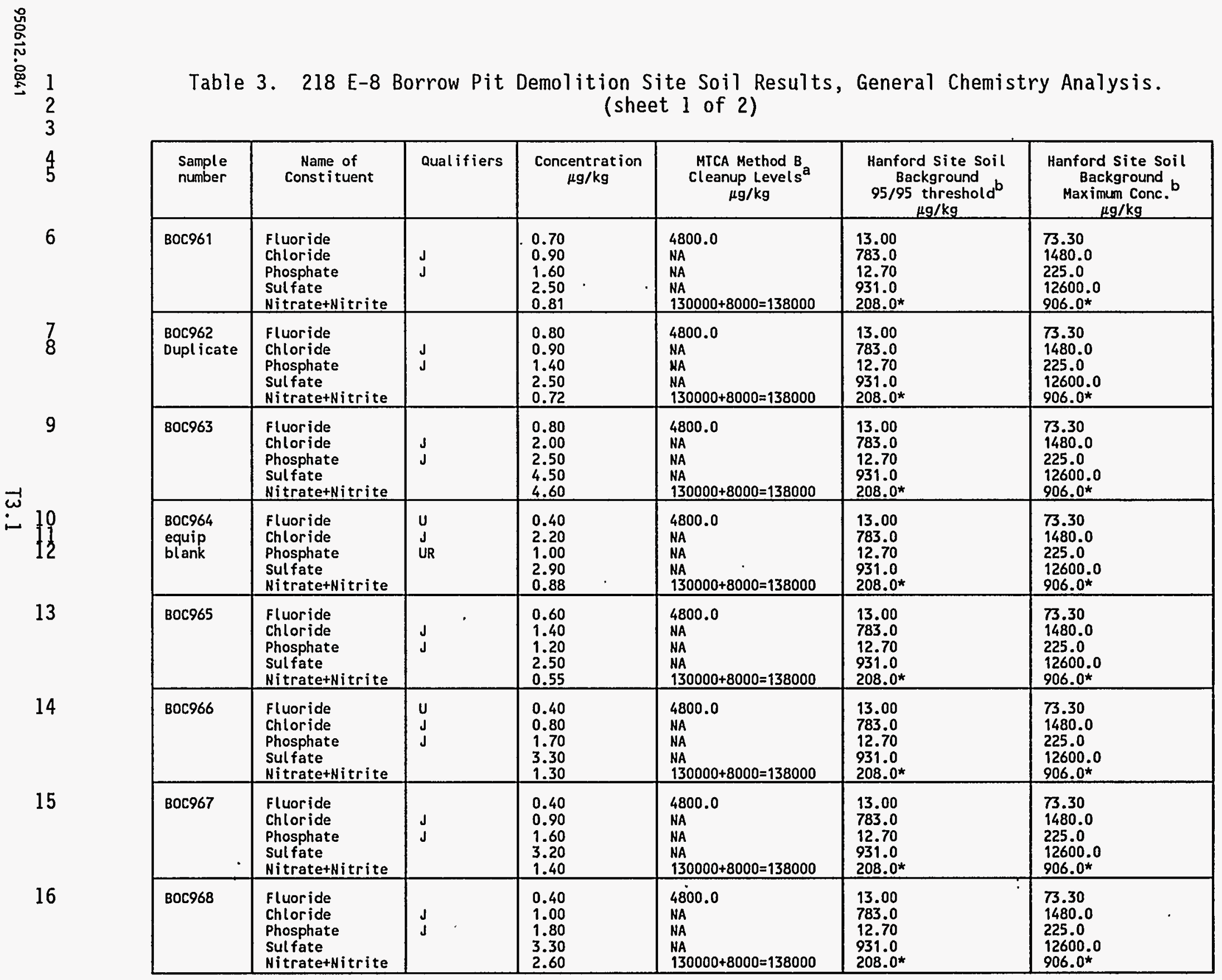


Table 3. 218 E-8 Borrow Pit Demolition Site Soil Results, General Chemistry Analysis.

(sheet 2 of 2)

1

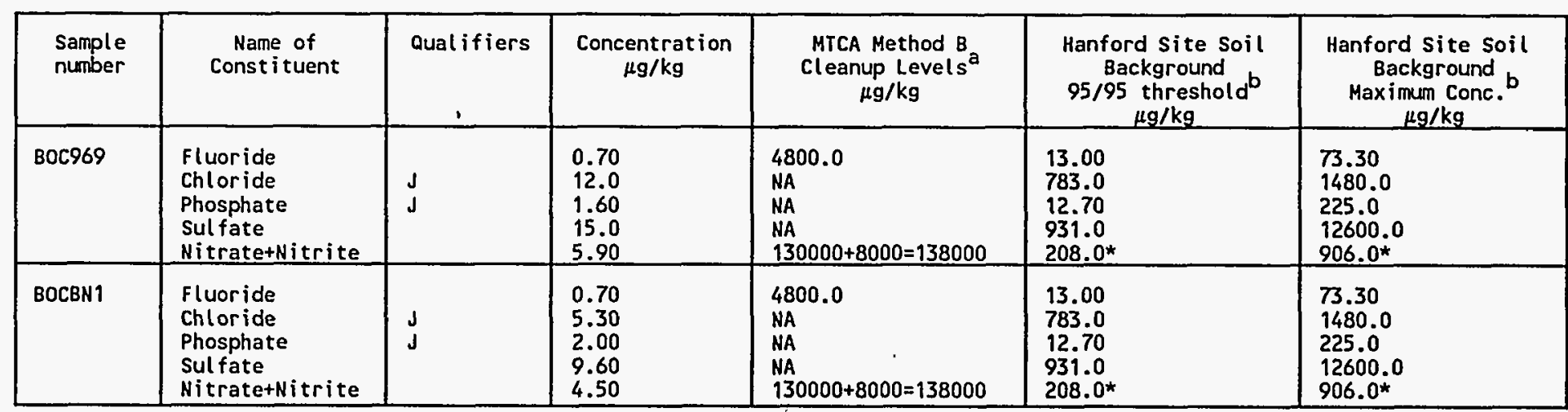

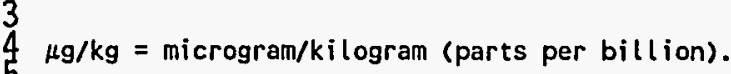

2

$5 *=N i$ trate concentration values only

$\vec{\omega}$

Note: Qualifiers are defined in Section 5.0, Data Validation.

N 10 Analytical methods are described in Section 4.1.

$N A=$ not available.

$\mathrm{J}=$ Indicates the compound or analyte was analyzed for and detected. The associated concentration is an estimate, by the laboratory because it is below the method detection limit.

$U=$ Indicates the compound or analyte was analyzed for and not detected in the sample.

19 UR = Indicates the compound or analyte was analyzed for and not detected in the sample. As a result of a major quality control deficiency identified 20 during data validation, the associated data have been qualified as unusable for decision making purposes.

$22^{a}=$ Calculation found in Model Toxic Control Act (173-340-740)

$24^{b}=$ DOE/RL, 1994, Hanford Site Background: Part 1, Soil Background for Nonradioactive Analytes, DOE/RL-92-24, Rev. 2 .

26 Note: MTCA, Method B, use the lowest of the two cleanup levels, cancer or noncancer-based, for implementation in closure plans 